UDC 339.338.1:339.5

DOI: https://doi.org/10.32782/2224-6282/159-24

Taraniuk Leonid
Doctor of Economic Sciences, Professor,
Sumy State University

Qiu Hongzhou

Experimenter

Henan Institute of Science and Technology (China) ORCID: https://orcid.org/0000-0001-8241-022X

Hlyboka Nataliia Undergraduate

Sumy State University

Таранюк Л. М. Сумський державний університет

Глибока Н. А.

Сумський державний університет

Цю Хунчжоу

Хенанський інститут науки та технологій (Китай)

\title{
MANAGEMENT OF TECHNOLOGICAL INNOVATIONS OF LOGISTICS ENTERPRISES BASED ON THE USE OF THE INTERNET OF THINGS
}

The development of logistics enterprises is an important symbol to measure the level of development of science and technology and comprehensive strength of a country, and the level of logistics and logistics intelligence, information level to reflect the value. Internet of Things technology provides a enough platform for logistics industry to realize the combination of traditional logistics technology and intelligent system operation management, so as to enable enterprises to realize logistics automation, information and intelligent operation faster and better. This paper describes the important role and innovative application of management of Internet of Things technology in the development of logistics enterprises, analyzes the advantages and disadvantages of RFID technology and its important role in inventory management optimization. With the rapid development of logistics enterprises, how to efficiently use the emerging Internet of Things technology and apply it to all aspects of logistics operation requires logistics enterprises to carry out technological innovation management on the basis of the original technology and equipment, seize the opportunity of national policies and put forward the innovation management mode suitable for enterprise development.

Keywords: innovative development, company, information technologies, logistics, potential, efficiency.

JEL classification: F23, L86, M15

\section{УПРАВЛІННЯ ТЕХНОЛОГІЧНИМИ ІННОВАЦІЯМИ ЛОГІСТИЧНИХ ПІДПРИСМСТВ НА ОСНОВІ ВИКОРИСТАННЯ ІНТЕРНЕТУ РЕЧЕЙ}

Розвиток логістичних підприємств є важливим індикатором для вимірювання рівня розвитку науки і техніки та загального потенціалу краӥни, а рівень логістики, логістичного інтелекту та інформації відображає його величину. Технологія Інтернету речей забезпечує достатню платформу в логістичній галузі для реалізації поєднання традиційних логістичних технологій та управління інтелектуальною системою управління, щоб дати змогу підприємствам швидще та краще реалізувати автоматизацію логістики, інформації та налагодження інтелектуальної роботи. У даній статті описується важлива роль та інновачійне застосування управління технології Інтернету речей у розвитку логістичних підприємств, аналізуються переваги та недоліки технологї RFID та ї̈ важлива роль в оптимізачії управління запасами. Завдяки стрімкому розвитку логістичних підприємств визначається, як ефективно використовувати нову технологію Інтернету речей та застосовувати ї̈ до всіх аспектів логістичної діяльності та вимагається, щоб логістичні підприємства здійснювали управління технологічними інноваціями на основі оригінальної технології та обладнання, користуючись можливістю національної політики та запропонувавщи режси управління інноваціями, який є придатним для розвитку підприємств. Авторами статті: досліджено проблемні аспекти управління технологічними інноваціями в роботі логістичних підприємств з використанням Інтернету речей з зазначенням впливу негативних факторів на господарську роботу логістичних підприємств. Проведено аналіз поточної ситуації розвитку управління технології Інтернету речей, в тому числі оцінюючи китайський та світовий досвід логістичної роботи підприємств та їх впливу на рівень циирровізації суб 'єктів господарювання. Обгрунтовано візуалізацію та інтелектуалізацію інноваџчій в логістичній роботі компаній, яка впливає на рівень продаж продукції, управління логістичними потоками, дистрибуцію продукиї та загальну ефективність логістичних компаній. Сформовано концептуальні засади управління RFID технологіями в роботі логістичних підприємств, яка базується на ефективному використанні системи Інтернету речей, формування організаційних прямих та зворотних зв 'язків між учасниками логістичного процесу та іншими стейкхолдерами. Визначено переваги та недоліки використання RFID технологій управління в роботі логістичних компаній.

Ключові слова: інноваційний розвиток, компанія, інформаційні технології, логістика, потенціал, ефективність.

(C) Taraniuk Leonid, Qiu Hunchdzhou, Hlyboka Nataliia, 2020 
Formulation of the problem. Innovation is a fundamental way for an enterprise to achieve core competitiveness, value enhancement and sustainable development, and an inexhaustible driving force for the development of human society. Innovation came into being in the early 20th century, first put forward by the famous economist Schumpeter in his book The Theory of Economic Development. Since the 1980s, driven by science and technology, elements such as information, technology, capital and talent have become more common in global flow and allocation, and scientific and technological innovation has become a decisive factor in national competitiveness. At the same time, more and more domestic scholars begin to pay close attention to the problem of innovation research, from pure western innovation theory is introduced to the empirical study of innovation activities in China, the research scope involves innovation mechanism, innovation mode, the innovation diffusion and transfer, technological progress and technological innovation, etc., has been initially formed with characteristic of our country innovation system theory research. Reform and opening-up, further understanding to the «science and technology is the first productivity», implement the development strategy of independent innovation, and put forward the construction of an innovative country, high-tech development and application of new technology, national industrialization and informatization achieved great progress, innovation as an important driver of world's economic and social development, more and more shows a huge role in the face of the new situation of economic development, the enterprise wants to get a good development, will have to constantly innovation [1, p. 14-15].

The progress of science and technology drives the development of the Internet of Things technology, logistics enterprises need the Internet of Things technology in all aspects such as storage management and distribution. Traditional logistics is mainly manual operation and manual mechanization management, less application of intelligent equipment and technology, logistics management cost is high and efficiency is low. After the development of emerging technologies, enterprises creatively apply them, which brings opportunities for the development of enterprises and also improves the efficiency of logistics operation.

Analysis of recent research and publications. Researchers such as Hongyan W. [2, p. 1-8] studied the technological innovations of logistics companies based on the use of the Internet of Things, which investigated the role of non-intercultural property in the logistics of companies using the Internet of Things. Scientists Donghua Z., Yi Z. [1, p. 8-15] unraveled the technology of innovation management using big data methods in the work of enterprises. Scientist Tian T. [3, p. 1-6] identified interdisciplinary aspects of communication technologies that are based on the Internet of Things. Scientist Jianfeng Z. [4, p. 23-30] considered the use of RFID technology in the logistics of manufacturing companies. Economist Minqing X. [5, p. 84-93] is studying e-commerce network models in his research. Scientist Xiaole H. [6, p. 51] studied in his work the tooling of the Internet of Things in the logistics distribution of companies. Scientist Yunhao L. [7, p. 1-288] studied the conceptual foundations of the introduction of Internet of Things technology in the work of Chinese enterprises. Economist Zhai P. [8, p. 162] considered the formation of applications for investment through the involvement of the Internet of Things in e-business and distribution. Scientist Youming T. [9, p. 32] formed a debating vision of the introduction of Internet of Things technology in the work of industrial and commercial companies. Scientists Jie Shao X., Fei H., Ji 'en S. [10, p. 70] studied the intellectual components in the work of enterprises that are built on the Internet of Things. Scientist Peiwei W. [11, p. 1-408] considered the formation of logistics networks of the Internet of Things in enterprise management.

Among the analyzed scientific works, it should be noted the lack of elaboration of technological innovation management using the Internet of Things in the work of logistics companies. Therefore, the authors take into account this study of management processes of technological innovation in the economic work of logistics companies.

Formulation of the goals of the article (task statement). The main purpose of the scientific article is to improve the management system of technological innovations using the Internet of Things system in the work of logistics companies.

The main objectives of the scientific article should include: research of problematic aspects of technological innovation management in the work of logistics enterprises using the Internet of Things; analysis of the current situation in the development of Internet of Things technology, including assessing the Chinese and world experience in logistics; substantiation of visualization and intellectualization of innovations in the logistics work of companies; formation of conceptual bases of management of RFID technologies in work of the logistic enterprises and definition of their advantages and disadvantages in use.

Presentation of the main research material. With the development of the world economy, the progress of science and technology and the change of ideas and concepts, the service economy, based on knowledge and information , has gradually replaced the traditional industrial economy and played an important role. The service industry has increasingly become the pillar industry of the global economic growth, and its development level has also become an important indicator to measure the degree of social and economic development. As one of the most important industries in modern service industry, logistics industry has been accelerated under the role of knowledge economy. There is no doubt that logistics, as an emerging industry in economic development, is an important embodiment of a country's scientific and technological level and comprehensive strength [1, p. 11].

At present, the Internet of Things technology is widely used in various fields of production and consumption. As a strategic emerging industry, the Internet of Things has good market benefits and development prospects. According to data, «In 2011, the market size of China's Internet of Things industry reached more than 260 billion yuan». At present, the emerging industries represented by the Internet of Things are advancing rapidly and orderly across the country. The government has increased investment in policies and funds to coordinate the allocation of various resources, so as to put China in a favorable position in the new round of information technology revolution. China since the eighteenth big future development strategies of the state determined the core idea is «improve our capacity for independent innovation, building an innovative country», in the big meeting of the party's 18 , clearly put forward the development strategy of «innovation driven» great idea, and points out that «science and technology 
innovation is to improve the strategic support of social productive forces and overall national strength, must be placed in the core of the national development and global position and plan with a global perspective and promote innovation, and improve the original innovation, integrated innovation and the introduction of digestion, absorption and innovation ability, pay more attention to the collaborative innovation», and other important policies .Modern logistics, as the «third profit source», cannot develop without the application of new technology. To improve the informatization and intelligentization of logistics is an urgent need to accelerate the development of logistics industry [3, p. 6].

China's logistics industry has developed to a certain scale, and various logistics enterprises are also in a state of fierce competition, and the construction of logistics related infrastructure is also steadily advancing. However, with the continuous development of the market and the changing demand, China's logistics industry has been difficult to meet the actual development needs. At present, the application of Internet of Things technology in logistics distribution mainly focuses on three aspects. First, the intelligent logistics distribution equipment. This mainly includes the application of RFID technology, which can realize dynamic monitoring of goods collection and transportation tracking, and can realize automation and intelligent development of logistics distribution. Second, logistics information system. Through the application of Internet technology, a comprehensive logistics information management can be established, which can track and manage the logistics information in different places and at different times. Third, the intelligent construction of products. Product traceability has always been the main purpose of the intelligent construction of logistics industry, and the use of bar code technology and other means can achieve this requirement, especially for some important goods transportation, product traceability technology is particularly important [9, p. 32].

The development of foreign logistics is based on technological innovation. Take the United States as an example. Since the 1960s, the United States began to explore and upgrade the distribution center of logistics, and began to introduce computer technology for logistics management. In addition to strengthening logistics innovation in terms of technology, the US logistics industry also leads the world in terms of operation mode. Most modern Logistics in the United States have completed the information construction, which provides a good foundation for the development of Internet of Things logistics. In China, the development of logistics industry started late. However, in recent years, China's logistics industry has taken the lead in the world in terms of information construction and the application of Internet of Things technology. On the one hand, the utilization rate of intelligent and automated equipment, such as robots and sensors, has been increasing in the logistics field, with an annual growth rate of $30 \%$ [10, p. 70].

The sensing layer of the Internet of Things is composed of various sensors and sensor gateways, including various sensors, two-dimensional code tags, RFID tags, readers, cameras and other sensing terminals, whose main functions are to identify objects and collect information. By using various technologies as support, the realization of the Internet of Things will improve the control over the production, distribution, storage, sales and other links of goods, change the traditional manual input information, achieve visual tracking, and combine innovative application of various technologies, which is conducive to the real-time monitoring of products and the improvement of logistics efficiency. Modern logistics systems are huge and complex, including logistics, capital flow, information flow and other information. They use automatic control, ERP and other intelligent technologies to provide support for logistics enterprises to realize production automation and just-in-time. Using key technologies such as data mining and intelligent scheduling to realize intelligent transportation and scheduling in a wide range of social logistics and transportation systems; Using automatic control, artificial intelligence, intelligent information management system and mobile computing technology, the traditional warehousing center will be built into an intelligent logistics center. Intelligent supply chain management based on logistics is realized by adopting intelligent computing and cloud computing technologies. Combine the application of various technologies to realize the intelligence of the whole logistics system [3, p. 1-2].

We must pay attention on Realization of RFID technology principles and functions. RFID technology adopts automatic identification technology to realize contactless interaction and processing between information on items and information system to information system, which builds a bridge between material and information, enabling material and information to be rapidly and efficiently converted, processed and fed back, forming the so-called "Internet of things". With the increasing maturity and cost reduction of RFID technology, it has been widely used in the field of logistics, mainly for information acquisition and logistics tracking, which has greatly improved the service level of logistics enterprises and even the whole industry. Realization of RFID technology functions in inventory management. RFID technology is applied to inventory management, there are mainly two ways: one is to use a fixed reader to read the goods information in the warehouse, and the information to the system database, and check. Second, the workers scan and check the electronic labels of the goods through a reader, and transmit the checked information to the system for checking. In inventory, because the goods have been put in storage, all the goods of all kinds of information (the number, location, etc.) are stored in the information management system, staff use handheld or forklift, speaking, reading and writing device reads the data in the pallet tags, pallet label recorded the actual number of items in the tray, can realize the data real-time transmission through the network; Or take a certain unit of time as the unit after the data collection, in the way of batch processing to the background management system. Therefore, the automatic collection method of RFID system can realize the automatic real-time partition inventory without any intervention, and ensure the rapid conduct of inventory operation and the accuracy of inventory data, facilitate the information docking, make the inventory simple, reduce the consumption of human and material resources, and increase the interests of enterprises [3, p. 5-6].

Advantages of RFID technology: RFID chip and RFID card reader has a strong corrosion resistance; the shape and size of RFID tags do not affect the accuracy of information reading; RFID technology identification accurate, flexible, can be barrier-free identification; RFID chip label can be repeatedly changed, refresh internal data, conducive to the real-time update of information; high security of data stor- 
age; RFID chip data capacity, to meet personalized needs. Disadvantages of RFID technology: technology maturity is still relatively deficient. RFID technology appears in a short time, the technology is not very mature. Due to the reverse reflectivity of UHF RFID electronic tags, it is difficult for them to be used in metal, liquid and other commodities; high cost - the price of RFID electronic tags is dozens of times more expensive than the ordinary bar code. Enterprises adopt a large number of such tags, which will greatly increase the cost, which will reduce the possibility of using RFID technology to a certain extent; technical standards are not unified. RFID tags in the market are of various types with different standards, which makes it difficult to transmit information in applications [4, p. 24].

Conclusions. In summary, based on the analysis of the advantages and disadvantages of RFID technology and the actual situation of warehouse management in many logistics enterprises, management. Suggestions are proposed: in the warehouse using RFID technology, use area is not too large, so as not to cause waste. In the warehouse, according to the use frequency of the shelves, the frequency of goods in and out of the use of selective use, not excessive use of RFID technology, to avoid the problem of cost increase caused by the full use; warehouse attic warehouse, the high floor does not use RFID technology, but the use of bar code technology, generally, C-commodities are placed in highrise buildings of attic warehouse, with low value, long shelf life and poor liquidity, besides, it is not necessary to check and take inventory frequently. It is actually a waste of resources to use RFID technology for management; electronic label picking area, three-dimensional warehouse and other areas using RFID technology. In these areas, the goods stored in general are goods with high liquidity, which need to be often shipped, the use of RFID technology can greatly improve work efficiency; in the inlet and outlet, set more advanced RFID door. In the goods in and out of the warehouse, can greatly improve the efficiency of delivery, to avoid the backlog of goods [5, p. 87-88].

The application of the Internet of things technology for the enterprise efficient operation opportunity, for the traditional logistics enterprises, technical innovation management, reference the advanced logistics management technology, seize national development policy of "smart" logistics opportunities as well as the national drive innovation environment support conditions, conducive to improve the efficiency of logistics operation, increase the logistics enterprise economic benefits, improve the logistics industry and the whole service level of service.

\section{References:}

1. Donghua Z., Yi Z. et al. (2013) Research on Technology Innovation Management Method in big Data Environment. Science of Science and Technology Management, no. 4, pp. 8-15.

2. Hongyan W. (2013) Intelligent Logistics Path based on The Internet of Things. Journal of Chongqing University of Technology (Social Science), no. 11, pp. 1-8.

3. Tian T. (2012) Interdisciplinary Research on Communication Based on The Internet of Things. Journal of Chongqing Technology and Business University; Social Sciences edition, no. 5, pp. 1-6.

4. Jianfeng Z. (2007) The Application Framework of RFID technology in logistics. Frontier Economy and Culture, no. 12, pp. 23-30.

5. Minqing X. (2014) Research on the Diversity of E-commerce Network Information Ecosystem Models. Modern Business, no. 17 , pp. 84-93.

6. Xiaole H. (2015) Application of Internet of Things Technology in Logistics Distribution. Market Modernization, no. 31 , p. 51.

7. Yunhao L. (2010) Introduction to Internet of Things. Beijing: Science Press, 288 p.

8. Pengxiang Z. (2015) Application of Internet of Things Technology in E-commerce Distribution. Electronic Production, no. 3 , p. 162.

9. Youming T. (2016) Discussion on the Application of Internet of Things Technology in Logistics distribution. Computer Knowledge and Technology, no. 22, p. 32.

10. Jie Shao X., Fei H., Ji 'en S. (2016) Research on intelligent Warehouse Based on Internet of Things Technology. Logistics Engineering and Management, no. 11, p. 70.

11. Peiwei W. (2016) Application research of Internet of Things Technology in Logistics warehouse Management. Xi'an: Xi'an University of Technology, 408 p. 